\title{
Reproduction of Ophioplocus januarii (Echinodermata: Ophiuroidea): a continuous breeder in northern Patagonia, Argentina
}

\author{
Martin I. Brogger ${ }^{1, *}$, Mariano I. Martinez ${ }^{1}$, Soledad Zabala ${ }^{2}$, \\ Pablo E. Penchaszadeh ${ }^{1}$ \\ ${ }^{1}$ Laboratorio de Ecosistemas Costeros, Museo Argentino de Ciencias Naturales 'Bernardino Rivadavia' - \\ CONICET. Av. Ángel Gallardo 470 (C1405DJR), Buenos Aires, Argentina \\ ${ }^{2}$ LARBIM, Centro Nacional Patagónico - CONICET. Bvd. Brown 2915 (U9120ACD), Puerto Madryn, Argentina
}

\begin{abstract}
We studied the reproduction of Ophioplocus januarii from Playa Villarino $\left(42^{\circ} 24^{\prime} \mathrm{S}\right.$, $\left.64^{\circ} 17^{\prime} \mathrm{W}\right)$, based on monthly samples collected between April 2005 and April 2007. Gonad indices were generally synchronous for males and females with little seasonal pattern. The changes of the gonad index were not significantly correlated with day length or water temperature. Histological analyses showed no evidence of seasonal differences in the maturation stages of the gonads, but that ovaries contained oocytes at different stages of development during the year. Thus, variations in the gonad index resulted from differences in the number of gametes in the gonads each month, suggesting that there are some periods when spawning intensity is higher than in others. Oocyte size-frequency analysis revealed only slight accumulation of large oocytes, with the largest oocytes over $400 \mu \mathrm{m}$ in diameter. This, together with the absence of oocytes being resorbed, suggests that gametes are being released continuously without a defined resting phase for the ovary. $O$. januarii breeds continuously, differing from the seasonal pattern of many other invertebrates living in shallow waters off the Patagonian coast as well as in other temperate seas, providing helpful information towards a better understanding of reproduction in Ophiuroidea.
\end{abstract}

KEY WORDS: Echinoderms - Brittle stars - Reproductive patterns - Temperate/tropical · Life history

\section{INTRODUCTION}

The regulation of a reproductive cycle involves not only synchrony during spawning but also covers several physiological and behavioral aspects of the organism. The duration of a cycle of reproduction may be interpreted as a function of growth rate, development and maturation of the gonadal tissues, and ending with spawning followed by a recovery period (Hendler 1991, Mercier \& Hamel 2009). The reproductive season of a species, usually expressed in terms of months, is generally defined as the time of year when most individuals of a certain population have many mature gametes ready to be spawned (Giese \& Pearse 1974). In some species, only 1 gametogenic cycle takes place for each individual during the reproductive period. The gametes can be released simultaneously or intermittently during each reproductive season (Giese \& Pearse 1974).

Among echinoderms and other marine invertebrates, the reproductive cycle usually shows annual, seasonal or monthly periodicity, comprising most of the individuals of certain populations (Fenaux 1970). The cyclic reproductive pattern is generally associated with habitats where environmental factors (day length, temperature, etc.) fluctuate according to a 
predictable regime. Nevertheless, continuous reproductive patterns have been proposed for some echinoderm species, particularly those with distributions close to the equator or in deep water (Hendler 1991). Several authors (e.g. Mercier \& Hamel 2009) suggest using the term 'aperiodic' to refer to the absence of a detectable pattern, because it is not clear whether gametes are released opportunistically (continuously), or if some proportion of the population follows a cyclic pattern that cannot be detected by conventional sampling and analysis techniques.

The search for environmental factors controlling reproductive timing in marine invertebrates has been the subject of many studies. According to Mercier \& Hamel (2009), the possible environmental factors that exert control on reproduction are poorly understood, and their identification largely speculative - mainly due to an incomplete understanding of how multiple and often overlapping environmental cycles can produce definite temporal patterns.

Although more than 2000 ophiuroid species are distributed from the intertidal to hadal depths, from the equator to polar regions (Stöhr et al. 2012), information on their reproductive biology still is relatively scarce (Stewart \& Mladenov 1995). This is particularly true for the Southern Hemisphere, where reproductive studies have been conducted for only a few species (Selvakumaraswamy \& Byrne 1995, Stewart \& Mladenov 1995, Falkner \& Byrne 2003, Grange et al. 2004, Byrne et al. 2008, Borges et al. 2009). The present study documents the reproductive biology of Ophioplocus januarii (Lütken, 1856) from the temperate waters of northern Patagonia, Argentina, through histological examination of the gonads and by the gonad index method.

\section{MATERIALS AND METHODS}

Specimens of Ophioplocus januarii were collected monthly by SCUBA divers from Playa Villarino $\left(42^{\circ} 24^{\prime} \mathrm{S}, 64^{\circ} 17^{\prime} \mathrm{W}\right)$ in the Gulf of San José, Argentina, from April 2005 to April 2007. Thirty individuals (10 to $20 \mathrm{~mm}$ disc diameter) were collected each month at a depth varying from 2 to $7 \mathrm{~m}$. In addition, a total of 10 small individuals $(<10 \mathrm{~mm}$ disc diameter) were dissected and observed under a microscope in order to examine their reproductive condition. The brittle stars are found in rocky and mixed gravelsand bottoms, usually hidden within algae or in crevices and holes in the bottom, which makes small individuals hard to find. The specimens were fixed in Bouin's fluid for $1 \mathrm{~d}$ and preserved in $70 \%$ ethanol.
Total body wet weight of each brittle star was determined with a Mettler precision balance $(0.0001 \mathrm{~g})$, and the disc diameter was measured to the nearest $0.1 \mathrm{~mm}$ with a Vernier caliper. The gonads of each individual were removed and their wet weight was determined. The gonad index was calculated using the formula $\mathrm{GI}=(\mathrm{GW} / \mathrm{BW}) \times 100$, where $\mathrm{GI}=$ gonad index $(\%), \mathrm{GW}=$ gonad wet weight $(\mathrm{g})$, and $\mathrm{BW}=$ whole body wet weight $(\mathrm{g})$.

Gonads were dehydrated in increasing ethanol concentrations and embedded in plastic resin (Historesin Leica), cut with a Leica microtome at $5 \mu \mathrm{m}$ thickness, and stained with hematoxylin and eosin. Gonad sections were examined under a Zeiss Axio Imager Z1 microscope, and photographed using an Axiocam HRc digital camera.

Oocyte size frequencies were determined by image analysis of ovary sections. All measurements were done using the software AxioVision version 4.4. Thirty to 200 oocytes were measured from each female (mean \pm SD: $98.8 \pm 49.2$ ) with a total of 13235 oocytes measured. Data were pooled to construct oocyte size-frequency histograms. The diameter of each oocyte was the mean value between the maximum diameter measure and its perpendicular at the centre of the oocyte. Only eggs sectioned through the nucleolus were measured to ensure that the eggs were measured consistently.

In order to observe the morphology of spermatozoa, testes were critical-point dried, cut in half and processed for scanning electron microscopy observations.

The sex of the brittle stars was determined by microscopic examination of portions of gonads, and confirmed by histological analysis. Chi-squared tests were used to test for significant differences in sex ratios during the whole study and each month individually. The significance of differences in GI mean values between samples was tested with a singlefactor ANOVA (with time as factor) (Zar 1999), and differences between the GI of males and females was tested with Student's $t$-test for independent samples. Normality and the homogeneity of variances of samples were examined using Kolmogorov-Smirnov and Levene's tests, respectively (Zar 1999). Correlations between day length, temperature and GI were calculated using Pearson's correlation coefficient (Sokal \& Rohlf 1995). Statistical analysis was carried out using the software Statistica version 6.0.

The water surface temperature in 2005 was obtained from satellite images from Antares network (www.antares.ws). The water temperature in 2006 and 2007 was recorded in situ using a digital thermometer (Hobo). 


\section{RESULTS}

Ophioplocus januarii is a gonochoric species with no evident sexual dimorphism; besides, it was not possible to sex individuals by the color of the gonads (variable between light brownish and whitish). Gonads are composed of multiple lobes in both males and females. Of the 750 brittle stars sampled, 355 were female and 395 were male. The sex ratio did not differ from 1:1 for the whole study $\left(\chi^{2}=2.1333, \mathrm{p}>0.05\right)$ or for each month (for all 25 months: $\mathrm{p}>0.05$ ).

Of the smaller brittle stars, no gonads were found in those measuring less than $7.6 \mathrm{~mm}$ in disc diameter, and in 2 undifferentiated of 7.8 and $7.9 \mathrm{~mm}$ (Table 1).

Table 1. Ophioplocus januarii. Microscopic observations of gonadal tissues of smaller individuals

\begin{tabular}{|lccc|}
\hline $\begin{array}{l}\text { Disc diameter } \\
(\mathrm{mm})\end{array}$ & $\begin{array}{c}\text { Presence } \\
\text { of gonads }\end{array}$ & Sex & $\begin{array}{c}\text { Developed } \\
\text { gametes }\end{array}$ \\
\hline 4.2 & No & - & - \\
5.4 & No & - & - \\
7.6 & Yes & Male & Yes \\
7.7 & Yes & Male & Yes \\
7.8 & No & - & - \\
7.9 & No & - & - \\
8.1 & Yes & Male & Yes \\
9.0 & Yes & Female & No \\
9.2 & Yes & Female & No \\
9.9 & Yes & Female & Yes \\
\hline
\end{tabular}

As of $7.6 \mathrm{~mm}$ diameter, the smallest males already carried spermatozoa, while females were recognizable from $9.0 \mathrm{~mm}$ disc diameter, although only those that were at least $9.9 \mathrm{~mm}$ presented fully grown oocytes (Table 1).

\section{Gonad index}

There were statistically significant variations in the monthly values of the GI (ANOVA; $F_{24,725}=13.109$, $\mathrm{p}<0.001)$. Although some lower and higher values are recognizable (Fig. 1), GI fluctuated with no clear pattern. There was no correlation between GI and day length (Pearson; $r=0.2845, p=0.168, n=25$ ) or between GI and water temperature (Pearson; $\mathrm{r}=$ $-0.1959, \mathrm{p}=0.348, \mathrm{n}=25$ ).

After sexing the individuals, it was possible to analyze the GI for both sexes (Fig. 2). Although significant differences were observed between the GI of males $(\mathrm{n}=395)$ and females $(\mathrm{n}=355)$ (Student's $t=$ $3.6972, \mathrm{p}<0.01)$, with the mean values of males being larger in general, the temporal patterns of the indices for both sexes were similar as the GI values of males and females were positively correlated (Pearson; $\mathrm{r}=0.8246, \mathrm{p}<0.001, \mathrm{n}=25)$. Even though the pattern is not definitive, it is possible to distinguish what appears to be a more-or-less mid-summer spawning pattern - suggested by a drop in values from December 2005 to February 2006, and again from October 2006 to January 2007.

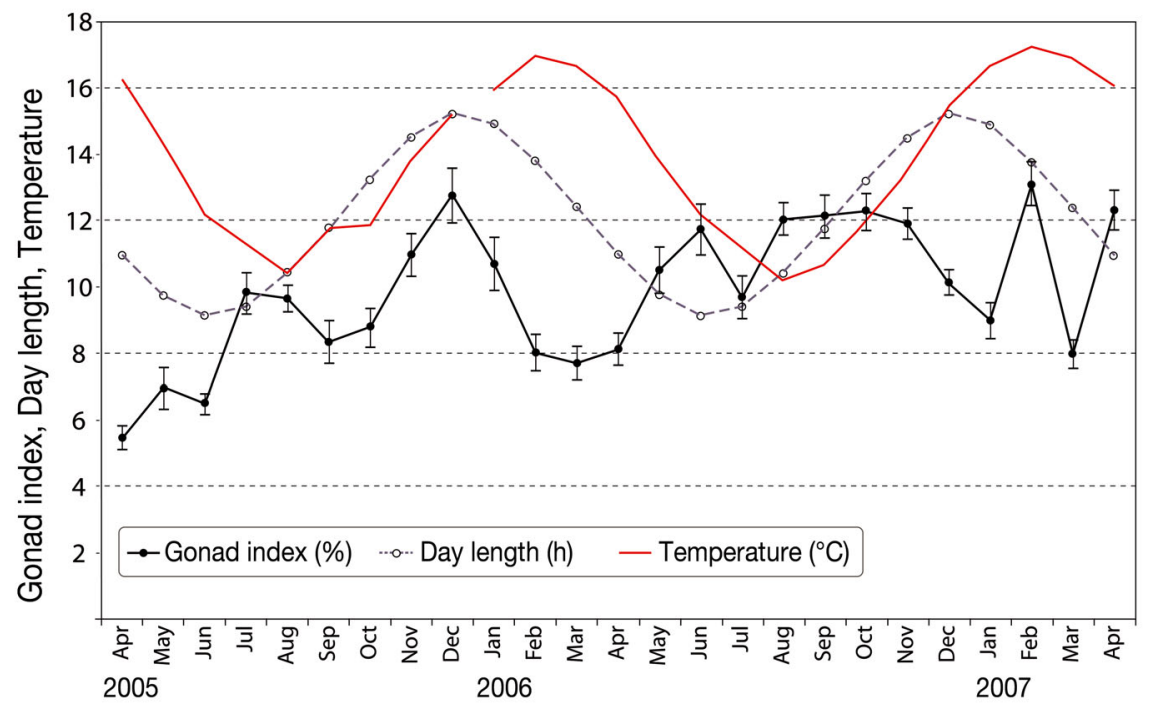

Fig. 1. Ophioplocus januarii. Mean monthly values of gonad index ( $\% \pm \mathrm{SE})$, day length (h), and water temperature $\left({ }^{\circ} \mathrm{C}\right)$ from April 2005 to April 2007; 30 individuals analyzed each month

\section{Histology}

Histological analysis was conducted for 134 females and 169 males. The gonads of Ophioplocus januarii are comprised of 2 sacs (an outer sac and an inner sac), with the germinal epithelium resting on the latter; the 2 sacs are separated by a genital coelom (Fig. 3A,D, Fig. 4A,F). It was not possible to recognize a gonoduct in either the ovaries or in the testes. No hermaphrodite individuals were found.

\section{Females}

The disc diameter of females was between 10.2 and $20.4 \mathrm{~mm}$ (mean \pm SD: $15.7 \pm 1.8 \mathrm{~mm}, \mathrm{n}=355)$. Over the 


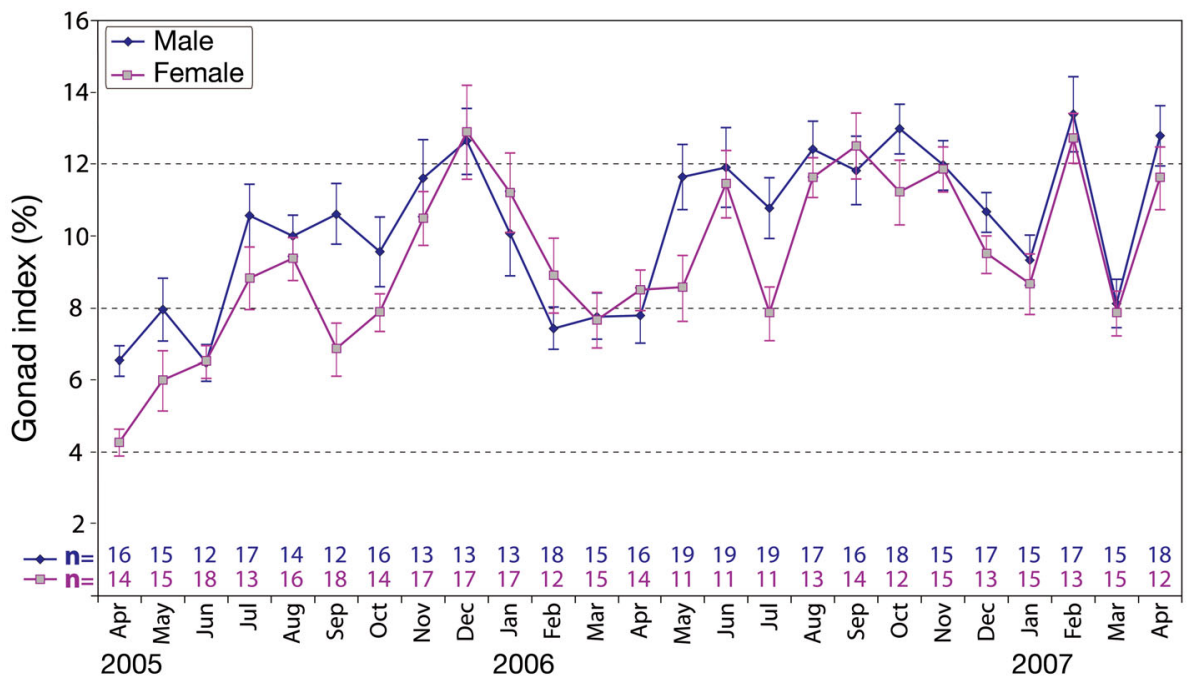

Fig. 2. Ophioplocus januarii. Mean monthly values of male and female gonad in$\operatorname{dex}(\% \pm$ SE) from April 2005 to April 2007; $\mathrm{n}=$ number of individuals of each sex for each month

study period, the ovaries contained oocytes in several stages of development simultaneously (Fig. 3). The most abundant oocytes were in the pre- and early vitellogenic stages $(<100 \mu \mathrm{m})$, followed by oocytes in intermediate stages of vitellogenesis (between 100 and $300 \mu \mathrm{m})$ and some in late-vitellogenic and fully grown stages $(>300 \mu \mathrm{m})$ (Fig. 3B,E). Yolk bodies and lipid droplets became apparent during the middle stages of development, although they were more abundant during the advanced and late stages of the vitellogenesis. Already at the early stages of development, each oocyte was surrounded by an epithelium with a histological resemblance to the inner sac (Fig. 3C).

Only 2 females (both from mid-summer samples) had ovaries in recovery or spent stages. These ovaries contained few fully mature oocytes together with several pre-vitellogenic oocytes. Resorption processes were not obvious in females, as no evidence of phagocytes were found. In the periphery of 1 ovary, which also contained oocytes in different stages of vitellogenesis, some brownish material was observed (possibly the products of oolysis) (Fig. 3F).

It was not possible to define the maturity stages for most individual females. Their ovaries contained a wide range of oocyte sizes with different maturation stages over the period studied. There was no significant accumulation of fully grown oocytes, even when small ovaries were observed. Thus, the size of the ovaries was related to the amount of eggs inside and not necessarily to the degree of development of the oocytes.
Males

The disc diameter of males was between 10.1 and $20.7 \mathrm{~mm}$ (mean \pm SD: $16.0 \pm 1.8 \mathrm{~mm}, \mathrm{n}=395$ ). Similar to females, the testes contained several stages of gametogenesis simultaneously (Fig. 4). Free spermatozoa were observed in the lumen of the testes, together with spermatogenic columns (Fig. 4A). The spermatogenic layer, composed of spermatogonia and spermatocytes, rests on the inner sac with the spermatogenic columns extending into the lumen (Fig. 4A,F).

For some testes, stages compatible with a partly spawned stage with free spaces in the lumen could be identified (Fig. 4C,D). Some individuals had all testes packed with spermatozoa with considerable reduction of the spermatocytes columns (Fig. 4B).

Resorption was evident in males, as indicated by presence of phagocytes in several testes (Fig. 4E). In some individuals, phagocytes were restricted to the lumen of the gonads, and were at the same time surrounded by a new generation of developing spermatocytes (Fig. 4F). Occasionally within the same male there were some testes undergoing resorption while the other testes were in a partly spawned stage. Other testes showed evidence of gamete release while the rest were fully packed with spermatozoa (Fig. 4C). Spermatozoa in the lumen of testes were present in all males analyzed, even when the testes were small.

The spermatozoa of Ophioplocus januarii has a spherical head (Fig. 5) with a depression at the anterior end where the acrosome is positioned, an annular band at the posterior end corresponding to the mitochondrial middle piece (Fig. 5D), and a prominent tail (Fig. 5C). The diameter of the head is constant $(3 \mu \mathrm{m})$.

\section{Oocytes size-frequency distribution}

The oocyte size-frequency distributions are shown as frequency histograms (Fig. 6). A large range of oocyte size-classes are present in all months. The diameter of the largest oocyte was over $400 \mu \mathrm{m}$. The oocyte size-frequency data show that there is almost no variation in the dominant oocyte size-classes over 


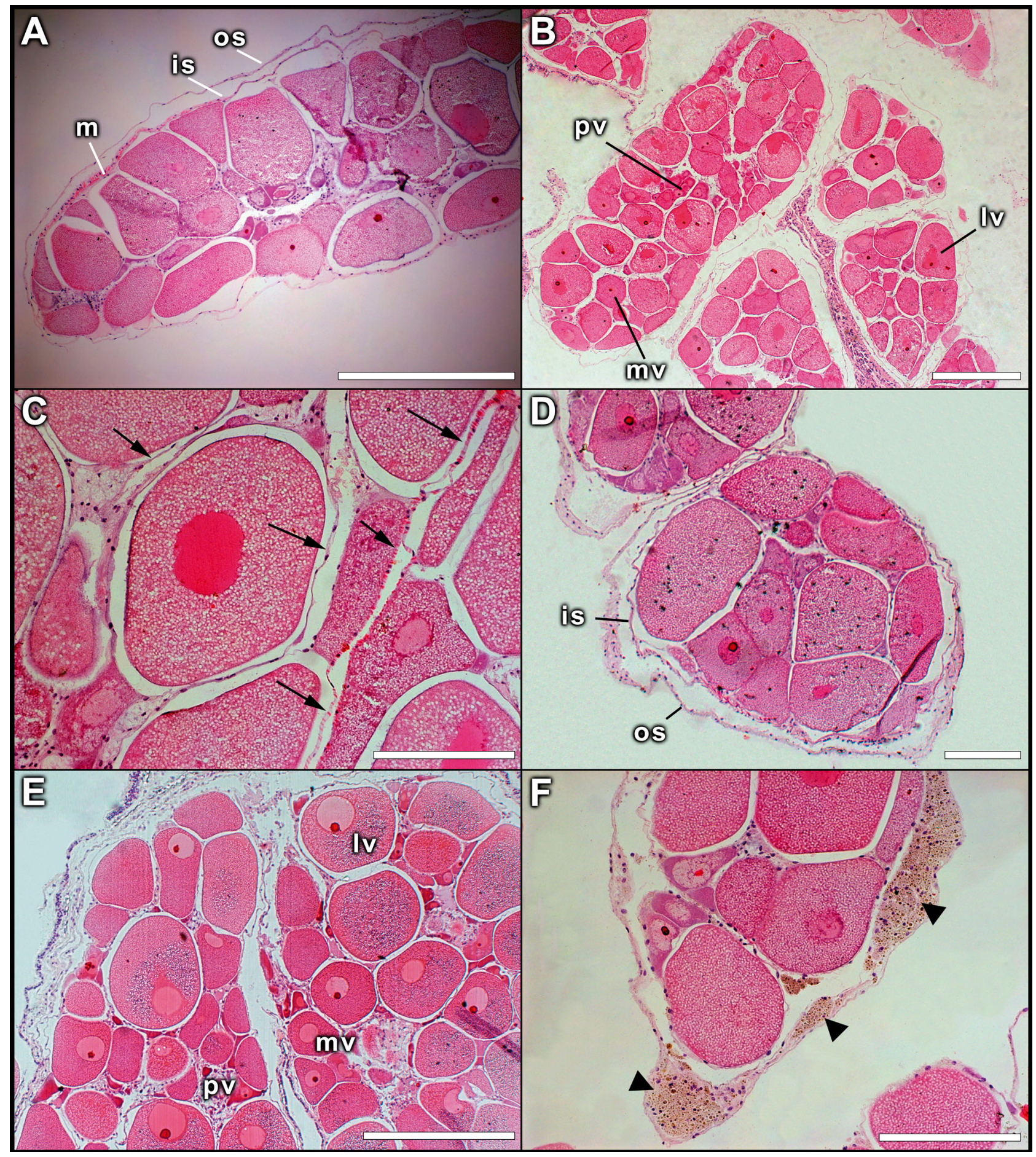

Fig. 3. Ophioplocus januarii. Histology of the ovaries. (A) Section containing oocytes at different developmental stages; the outer sac (os), the inner sac (is) and the myoepithelial cells (m). (B) Section containing a wide range of oocyte sizes; oocytespv: pre-vitellogenic, mv: mid-vitellogenic, lv: late-vitellogenic. (C) Detail of the epithelial layer that surrounds each oocyte (arrows); note its histological resemblance to the walls of the inner sac. (D) Smaller ovaries, where it is possible to observe oocytes at different stages of vitellogenesis; the outer sac (os) and the inner sac (is). (E) Ovaries containing oocytes at different developmental stages; a pre-vitellogenic oocyte (pv), a mid-vitellogenic oocyte (mv) and a late-vitellogenic oocyte (lv). (F) Ovary with brownish material (arrow heads) on its periphery; note the presence of oocytes at different stages of vitellogenesis. Scale bars: $\mathrm{A}, \mathrm{B}, \mathrm{E},=500 \mu \mathrm{m} ; \mathrm{C}, \mathrm{D}, \mathrm{F},=200 \mu \mathrm{m}$ 


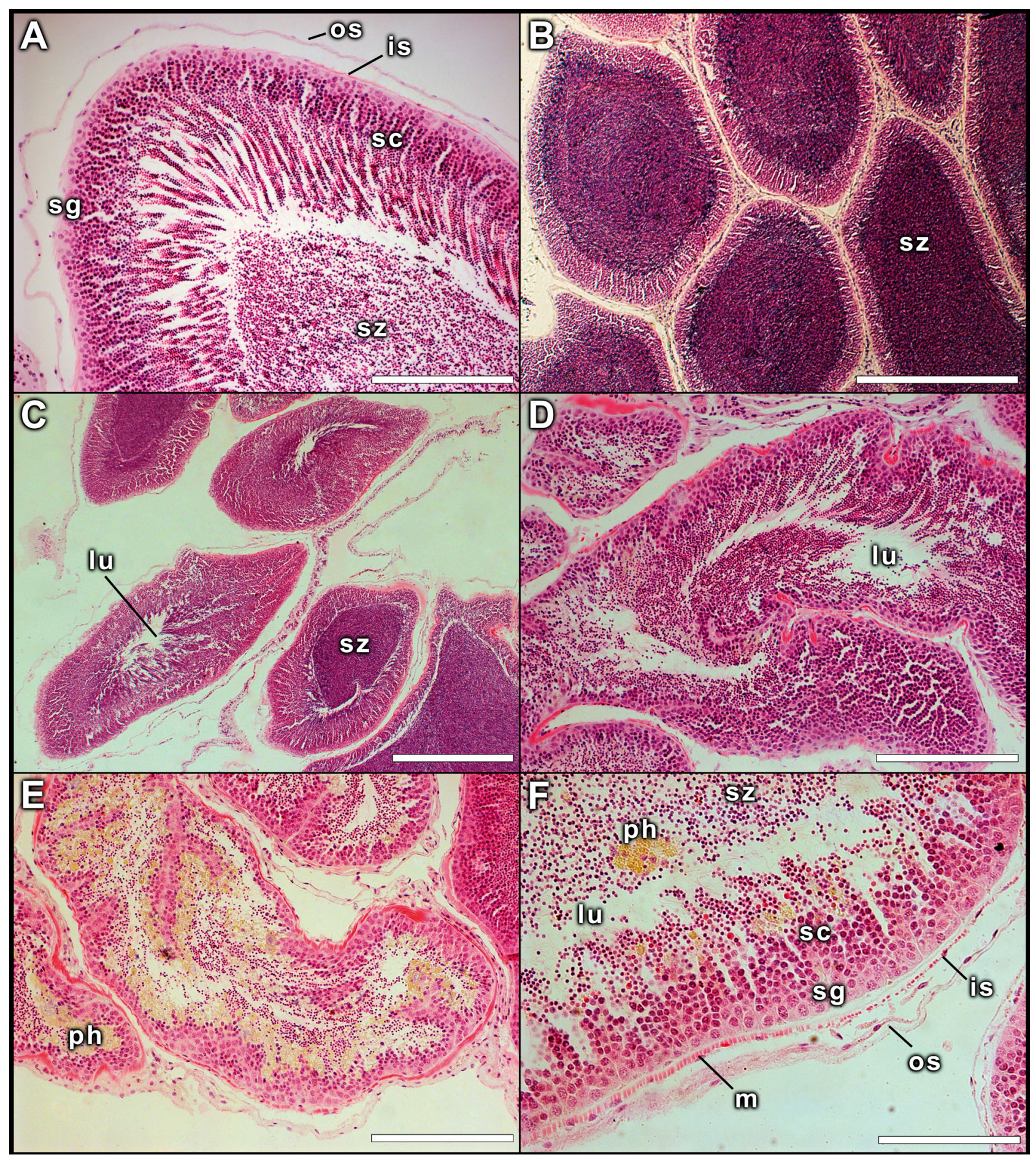

Fig. 4. Ophioplocus januarii. Histology of the testes. (A) Detail of a growing testis with spermatozoa (sz), columns of spermatocytes (sc) and spermatogonia (sg); arrows indicate the outer sac (os) and the inner sac (is). (B) Testes packed with spermatozoa (sz); the spermatocyte columns are reduced. (C) Testes in 2 different stages of development simultaneously; note the space within the lumen (lu) of 1 testis while the other contains a dense mass of spermatozoa (sz). (D) Detail of a partly spawned testis; note the gap in the lumen (lu) evidencing gamete release. (E) Testes with evidences of resorption; note the phagocytes (ph). (F) Detail of a testis containing spermatozoa (sz), spermatocyte columns (sc) and spermatogonia (sg); note the empty space in the lumen (lu) and the presence of phagocytes (ph); the outer sac (os), the inner sac (is) and the myoepithelial cells (m) are indicated. Scale bars: A, D, E $=200 \mu m_{i} B, C=500 \mu m_{i} F=100 \mu \mathrm{m}$ 


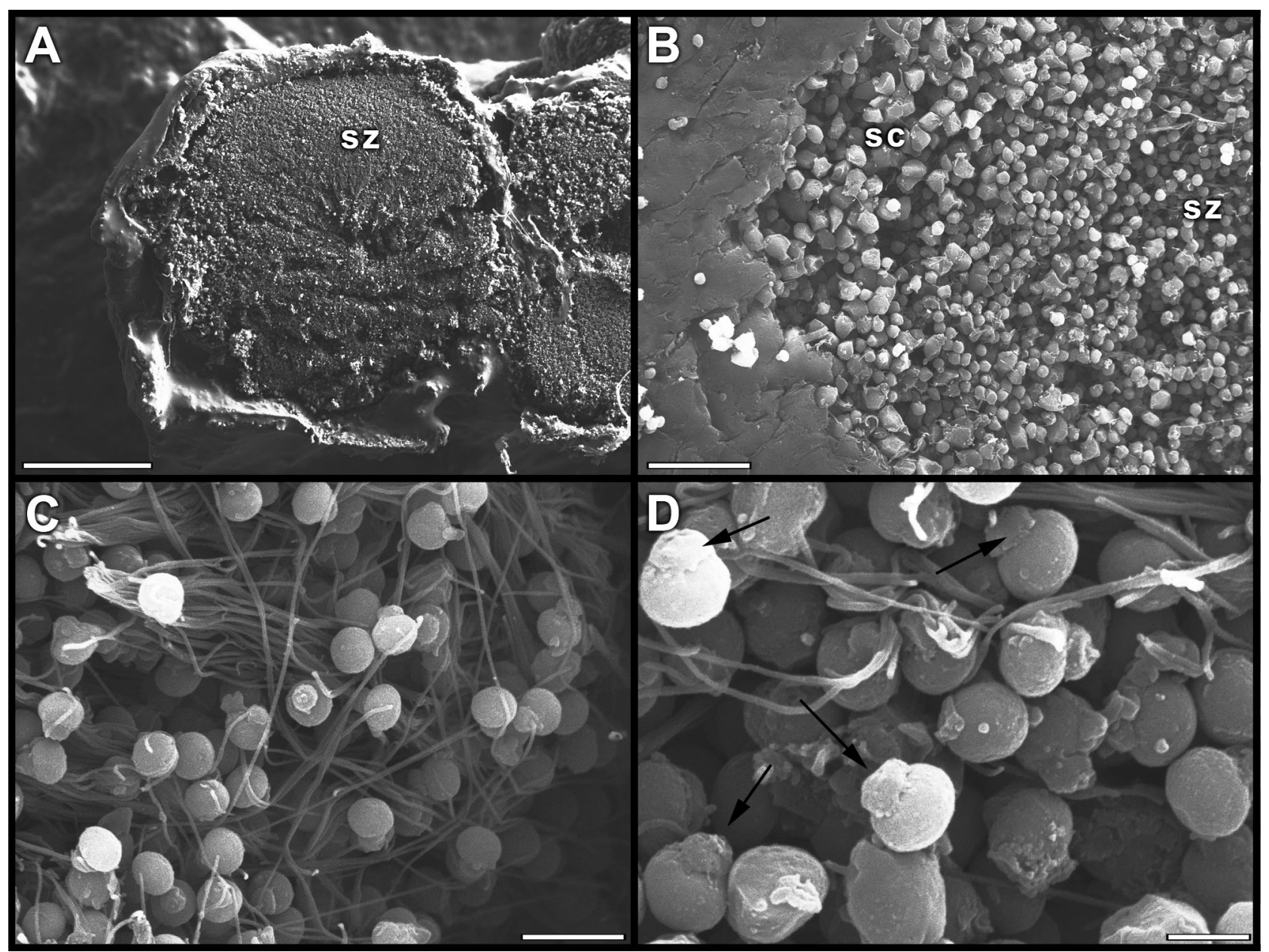

Fig. 5. Ophioplocus januarii. Section of a testis under scanning electron microscopy. (A) General view of a section in 1 lobe containing spermatozoa (sz). (B) Detail of the section along the edge of the testis; it is possible to recognize spermatocytes (sc) and spermatozoa (sz). (C) Detail of the centre of the lobe, filled with spermatozoa with long tails. (D) Detail of the heads of spermatozoa; the arrows point to the mitochondrial middle piece. Scale bars: $A=200 \mu m_{;} B=20 \mu m_{i} C=5 \mu m ; D=2 \mu m$

the months. The pre-vitellogenic oocytes $(<100 \mu \mathrm{m})$ are most frequent. Vitellogenic oocytes $(>300 \mu \mathrm{m})$ are present in all samples. It is possible to recognize a second peak of these size-classes in late spring and early summer, but always with less frequency than the other peak of small oocytes. It was not possible to identify accumulation of large oocytes in any female. Even in months where the second peak appears, the percentage of oocytes with fully mature diameters was less than $15 \%$.

\section{DISCUSSION}

According to Hendler (1991), studies of ophiuroid reproduction indicate that the duration and seasonality of the phases of gametogenesis are highly va- riable, with spawning periods longer than 3 mo. This has been confirmed in several studies (Selvakumaraswamy \& Byrne 1995, Falkner \& Byrne 2003, Grange et al. 2004, Borges et al. 2009). Continuous breeding has been typically related to warm-water and deepsea species, with a trend toward longer spawning periods in the lower latitudes (Hendler 1991), even though for some deep-sea species a reproductive seasonality has been reported (Tyler \& Gage 1980, 1982, Gage et al. 2004). Based on the histological analysis of Ophioplocus januarii, a cyclic pattern with typical gametogenic stages could not be distinguished. Instead, the simultaneous presence of gametes in different maturation stages in the gonads suggests an aperiodic pattern of reproduction. Since nearly the same reproductive condition was observed for all individuals of the population (especially within fe- 


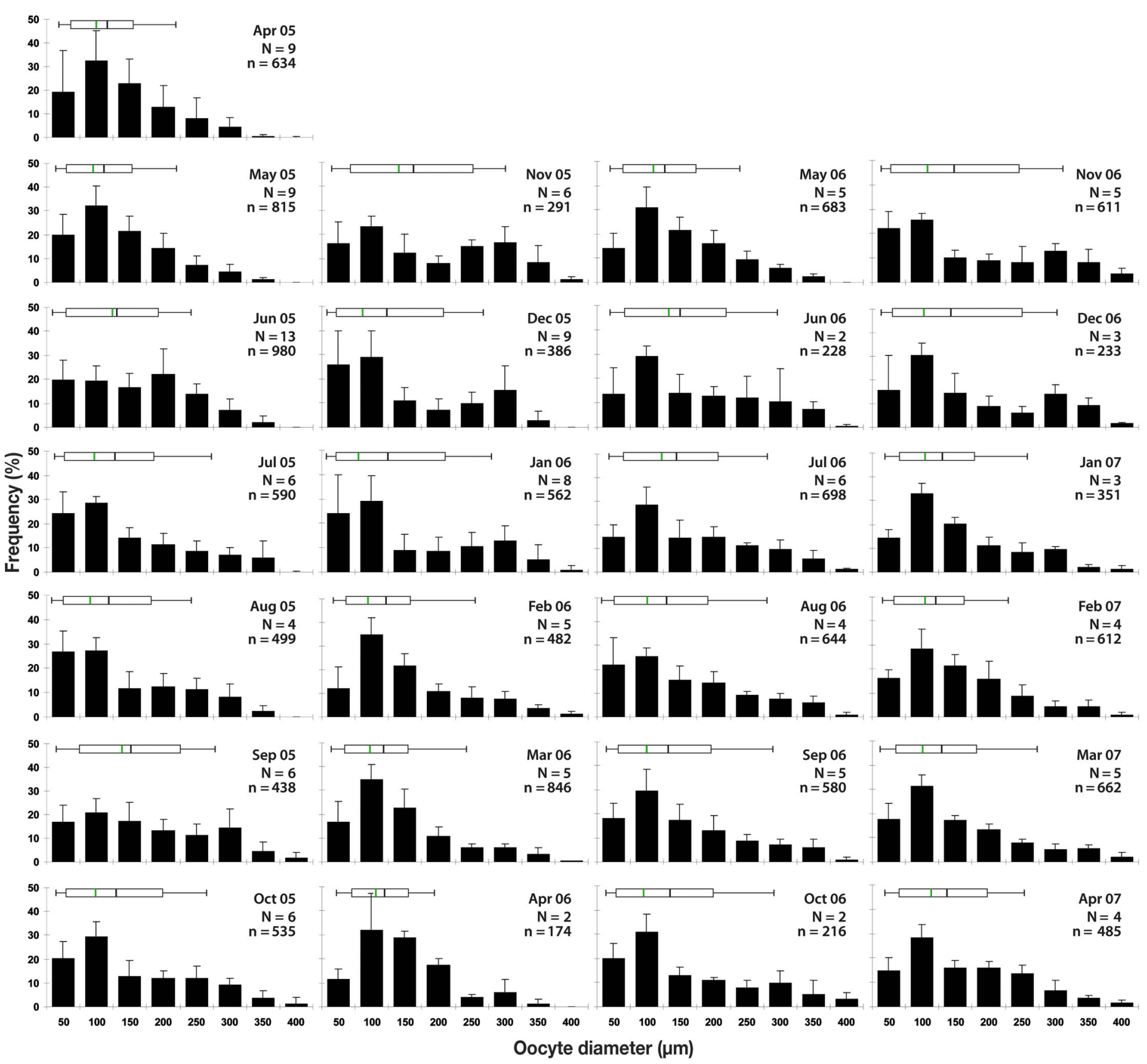

Fig. 6. Ophioplocus januarii. Oocyte size-frequency data for samples collected between 2005 and 2007 . Histograms show frequencies of different oocyte size-classes each month $( \pm \mathrm{SD})$, where $\mathrm{N}=$ number of females, $\mathrm{n}=$ number of oocytes measured, and monthly box plots cover the oocyte diameter range. The left and right limits of the boxes indicate the 25th and 75 th percentiles, box whiskers indicate the 10th and 90th percentiles; the mean (black line in box plot) and median (green line in box plot) of the oocyte range for each month is also shown

males), it is unlikely this is a case of asynchronous cycle of reproduction. Slight asynchrony in gonad condition within the testes of a few males does not change this conclusion. Thus, the shallow water population of $O$. januarii in the temperate waters of northern Patagonia presents a truly continuous re- productive cycle. This is similar to the ovoviviparous Ophiolepis paucispina, in which reproduction is continuous and the ovaries contain oocytes at different stages of development throughout the year (Byrne 1989), and very reminiscent of that in Ophiomusium lymani from deep waters off Scotland (Gage \& Tyler 
1982) which shows no annual periodicity in oogenesis, with gonads remaining active at low levels throughout the year.

Although Ophioplocus januarii reproduces continuously throughout the year, a variation of the gonad index was observed. The fluctuations of the values over time could suggest that the intensity of spawning is higher in some months of mid-summer. This has also been reported for populations of Ophiophragmus filograneus, Ophiothrix angulata and Ophiothrix quinquemaculata, which spawn with several degrees of intensity through the year, but with peaks of gamete release in the spring, early summer or autumn (Guille 1964, Stancyk 1974, 1975). The lack of a defined season of full maturity stage in $O$. januarii, together with limited resorption, suggests gametes are being released continuously, without a defined resting phase. In the subtropical species Microphiopholis gracillima, the gonad index is always high and the population spawns several times, while the ovaries contain many pre- and early vitellogenic oocytes and only a few late- or fully grown oocytes, indicating that females frequently spawn a limited, low number of oocytes (Singletary 1980). In $O$. januarii, variations in the mean values of the gonad index are not related to changes in the maturity stages of the gametes, which have been reported for many other ophiuroids (Hendler 1991). Instead, these variations can be related to differences in the amount of gametes (and thus, the size of the gonads) produced each month. Some variation in male gonad index could also be attributed to asynchronous spermatogenesis within testes. For this population of $O$. januarii, it was not possible to characterize the reproduction only by assessing the gonad index; histological studies and oocyte size-frequency analyses were also required.

Occasionally, a marked individual asynchrony in reproductive periodicity can result in continuous spawning (Mladenov 1976, 1983, Hendler 1991). The histological analysis of the ovaries in Ophioplocus januarii, together with oocyte size-frequencies for each female, revealed no asynchrony in general terms among individuals. O. januarii may represent a transition between tropical and subtropical patterns of continuous reproduction and the temperate pattern of reproductive cycles with a clear seasonality of spawning. Many other shallow water invertebrates from the study area have a defined seasonal reproductive cycle; e.g. echinoids (Marzinelli et al. 2006, Brogger et al. 2010), asteroids (Rubilar et al. 2005, Pastor de Ward et al. 2007), and gastropods (Bigatti et al. 2008, Averbuj \& Penchaszadeh 2010). As the pres- ent work was conducted with a population near the southern limit of the species' distribution (Brogger et al. 2013), reproduction of tropical water populations from northern Brazil would be expected to be similar to that observed here, as further north there would be even less environmental seasonality.

The gonads of Ophioplocus januarii are similar to those of other ophiuroids, with 2 sacs separated by a genital coelom. The germinal epithelium of males rests on the inner sac. The walls of the inner and outer sacs contain epithelial cells and myoepithelial cells, a characteristic of echinoderm coelomic epithelia (Byrne 1991). Because several stages of oogenesis were present at the same time in the ovaries of $O$. januarii, it was not possible to identify a distinct germinal layer. Byrne (1989) also observed this in Ophiolepis paucispina. She recognized oogonial proliferation not only near the base but also elsewhere in the ovaries, and suggested that there may not be a discrete proliferative region. Because oocyte types are not spatially segregated, the precise relationship between the oocytes and the gonadal wall is difficult to understand and has been poorly documented (Hendler 1991). Traditionally, oogenesis in echinoderms is described to be solitary or 'follicular' (Walker 1982). In the latter condition, the oocytes are immersed in the haemal fluid and are surrounded by 'follicular' cells. The 'follicle' covers the oocyte throughout its development. Usually an attachment area comprised of specialized attachment cells links the oocytes to the surrounding epithelium, and has been suggested to provide structural and nutritive support to developing oocytes (Moloney \& Byrne 1994). No attachment complex was observed in $O$. januarii. The oocytes are surrounded by an epithelium similar to, and probably derived from, the inner sac. Haemal fluid was not observed at the periphery of the oocytes, and oogenesis in $O$. januarii is solitary. Byrne (1989) described solitary oogenesis in Ophiolepis paucispina with the somatic cells surrounding the oocytes appearing to provide structural support.

The sperm morphology in Ophioplocus januarii is similar to that of other ophiuroid species (Yamashita \& Iwata 1983). The spermatozoa are composed of a spherical head with the acrosome positioned at the anterior end in a depression, a short but conspicuous mitochondrial middle piece at the posterior end, and a prominent tail. They exhibit the 'basic' morphology found among animals in which external fertilization occurs, even including some brooding or hermaphroditic species (Chia et al. 1975, Hendler 1991). The diameters of the fully developed oocytes in O. januarii were over $400 \mu \mathrm{m}$, which suggests lecithotrophic 
development, probably through vitellaria larvae (Hendler 1991, Selvakumaraswamy \& Byrne 2006). Ophioplocus japonicus, with a maximum oocyte diameter of $300 \mu \mathrm{m}$, has vitellaria larvae that complete development within 6 d (Komatsu \& Shosaku 1993), whereas Ophioplocus esmarki from central California is a seasonal brooder with brooding period from April to September (a summer brooder), and it has a maximum oocyte diameter (live) of $328 \mu \mathrm{m}$ (Rumrill \& Pearse 1985).

Evidently the reproduction of Ophiuroidea covers a wide range of highly variable and different strategies. The absence of a reproductive periodicity in temperate shallow waters of the SW Atlantic, as here observed for Ophioplocus januarii, represents a clear example of that variation. Perhaps for this species, environmental seasonality, which affects the cycle of primary production, is reflected in a seasonal cycle of larval survival, determining recruitment each year. This was previously observed by Gage \& Tyler (1982) for Ophiomusium lymani in the deep waters of the NE Atlantic, where recruitment is controlled not by a gametogenic cycle, but by seasonal periodicity in downward flux of sediment food particles. The presence of mature gametes in the smaller individuals observed here suggest early maturity in $O$. januarii. Future growth studies may present this species as having many reproductive years, adding even more variability to its reproductive strategy.

Acknowledgements. We are very grateful to J. M. Lawrence for improving this article with critical observations, useful suggestions and language corrections. Many thanks to J. Pearse and one anonymous referee for their revision and invaluable comments. Special thanks to E. Zavattieri and O. Wheeler for their help during the sample collection, and to C. Sánchez Antelo for histological assistance. The authors are members of CONICET. This work was partially supported by ANPCyT PICT-2012-0561 and CONICET PIP-0253.

\section{LITERATURE CITED}

Averbuj A, Penchaszadeh PE (2010) Reproductive seasonality, oviposition and development of the Nassarid whelk Buccinanops cochlidium (Dillwyn, 1817) in Patagonia, Argentina. J Molluscan Stud 76:25-32

> Bigatti G, Marzinelli EM, Penchaszadeh PE (2008) Seasonal reproduction and sexual maturity in Odontocymbiola magellanica (Neogastropoda, Volutidae). Invertebr Biol 127:314-326

> Borges M, Yokoyama LQ, Amaral ACZ (2009) Gametogenic cycle of Ophioderma januarii, a common Ophiodermatidae (Echinodermata: Ophiuroidea) in southeastern Brazil. Zoologia (Curitiba) 26:118-126

Brogger MI, Martinez MI, Penchaszadeh PE (2010) Reproduction of the sea urchin Arbacia dufresnii (Echinoidea:
Arbaciidae) from Golfo Nuevo, Argentina. J Mar Biol Assoc UK 90:1405-1409

Brogger MI, Gil DG, Rubilar T, Martinez MI and others (2013) Echinoderms from Argentina: biodiversity, distribution and current state of knowledge. In: Alvarado JJ, Solís Marín F (eds) Echinoderm research and diversity in Latin America. Springer, Berlin, p 359-402

Byrne M (1989) Ultrastructure of the ovary and oogenesis in the ovoviviparous ophiuroid Ophiolepis paucispina (Echinodermata). Biol Bull 176:79-95

Byrne M (1991) Reproduction, development and population biology of the Caribbean ophiuroid Ophionereis olivacea, a protandric hermaphrodite that broods its young. Mar Biol 111:387-399

> Byrne M, Cisternas P, O'Hara T (2008) Brooding of pelagictype larvae in Ophiopeza spinosa: reproduction and development in a tropical ophiodermatid brittlestar. Invertebr Biol 127:98-107

Chia F, Atwood D, Crawford B (1975) Comparative morphology of echinoderm sperm and possible phylogenetic implications. Am Zool 15:533-565

Falkner I, Byrne M (2003) Reproduction of Ophiactis resiliens (Echinodermata: Ophiuroidea) in New South Wales with observations on recruitment. Mar Biol 143: 459-466

Fenaux L (1970) Maturation of the gonads and seasonal cycle of the planktonic larvae of the ophiuroid Amphiura chiajei Forbes. Biol Bull 138:262-271

Gage JD, Tyler PA (1982) Growth and reproduction of the deep-sea brittlestar Ophiomusium lymani Wyville Thomson. Oceanol Acta 5:73-83

Gage JD, Anderson RM, Tyler PA, Chapman R, Dolan E (2004) Growth, reproduction and possible recruitment variability in the abyssal brittle star Ophiocten hastatum (Ophiuroidea: Echinodermata) in the NE Atlantic. DeepSea Res 51:849-864

Giese AC, Pearse JS (1974) Introduction: general principles. In: Giese AC, Pearse JS (eds) Reproduction of marine invertebrates, Vol 1: acoelomate and pseudocoelomate metazoans. Academic Press, New York, NY, p 1-49

> Grange LJ, Tyler PA, Peck LS, Cornelius N (2004) Long-term interannual cycles of the gametogenic ecology of the Antarctic brittle star Ophionotus victoriae. Mar Ecol Prog Ser 278:141-155

Guille A (1964) Contribution à l'étude de la systématique et de l'écologie d'Ophiothrix quinquemaculata d. Ch. Vie Milieu 15:243-308

Hendler G (1991) Echinodermata: Ophiuroidea. In: Giese A, Pearse JS, Pearse VB (eds) Reproduction of marine invertebrates, Vol VI: echinoderms and lophophorates. Boxwood Press, Pacific Grove, CA, p 351-511

Komatsu M, Shosaku T (1993) Development of the brittle star, Ophioplocus japonicus H. L. Clark. Zoolog Sci 10: 295-306

Marzinelli EM, Bigatti G, Giménez J, Penchaszadeh PE (2006) Reproduction of the sea urchin Pseudechinus magellanicus (Echinoidea: Temnopleuridae) from Golfo Nuevo, Argentina. Bull Mar Sci 79:127-136

Mercier A, Hamel JF (2009) Endogenous and exogenous control of gametogenesis and spawning in echinoderms. Adv Mar Biol 55:1-291

Mladenov PV (1976) Reproduction and larval development in ophiuroids (Echinodermata) of Barbados, West Indies. MA thesis, McGill University, Montreal

Mladenov PV (1983) Breeding patterns of three species of 
Caribbean brittle stars (Echinodermata: Ophiuroidea). Bull Mar Sci 33:363-372

Moloney P, Byrne M (1994) Histology and ultrastructure of the ovary and oogenesis in the ophiuroid Ophionereis schayeri. In: David B, Guille A, Féral JP, Roux M (eds) Echinoderms through time. Balkema, Rotterdam, p 463-469

Pastor de Ward CT, Rubilar T, Díaz de Vivar ME, Gonzalez Pisani X, Zarate E, Kroeck M, Morsan E (2007) Reproductive biology of Cosmasterias lurida (Echinodermata: Asteroidea) an anthropogenically influenced substratum from Golfo Nuevo, Northern Patagonia (Argentina). Mar Biol 151:205-217

Rubilar T, Pastor de Ward CT, Díaz de Vivar ME (2005) Sexual and asexual reproduction of Allostichaster capensis (Echinodermata: Asteroidea) in Golfo Nuevo. Mar Biol 146:1083-1090

Rumrill SS, Pearse JS (1985) Contrasting reproductive periodicities among north-eastern Pacific ophiuroids. In: Keegan BF, O'Connor BDS (eds) Echinodermata: proceedings of the 5th international echinoderm conference. AA Balkema, Rotterdam, p 633-638

Selvakumaraswamy P, Byrne M (1995) Reproductive cycle of two populations of Ophionereis schayeri (Ophiuroidea) in New South Wales. Mar Biol 124:85-97

Selvakumaraswamy P, Byrne M (2006) Evolution of larval form in ophiuroids: insights from the metamorphic of Ophiothrix (Echinodermata: Ophiuroidea). Evol Dev 8: 183-190

Singletary R (1980) The biology and ecology of Amphioplus coniortodes, Ophionepthys limicola, and Micropholis

Editorial responsibility: Anna Metaxas,

Halifax, Nova Scotia, Canada gracillima (Ophiuroidea: Amphiuridae). Caribb J Sci 16: 39-55

Sokal RR, Rohlf FJ (1995) Biometry: the principles and practice of statistics in biological research. Freeman, New York, NY

Stancyk SE (1974) Life history patterns of three estuarine brittlestars (Ophiuroidea) at Cedar Key, Florida. PhD thesis, University of Florida, Gainesville, FL

Stancyk SE (1975) The life history pattern of Ophiothrix angulata (Ophiuroidea). Am Zool 15:793

Stewart BG, Mladenov PV (1995) Reproductive periodicity in the euryalinid snake star Astrobrachion constrictum in a New Zealand fiord. Mar Biol 123:543-553

Stöhr S, O'Hara TD, Thuy B (2012) Global diversity of brittle stars (Echinodermata: Ophiuroidea). PLoS ONE 7: e31940

Tyler PA, Gage JD (1980) Reproduction and growth of the deep-sea brittlestar Ophiura ljungmani (Lyman). Oceanol Acta 3:177-185

Tyler PA, Gage JD (1982) Ophiopluteus Ramousus, the larval form of Ophiocten gracilis (Echinodermata: Ophiuroidea). J Mar Biol Assoc UK 62:485-486

Walker CW (1982) Nutrition of gametes. In: Jangoux M, Lawrence JM (eds) Echinoderm nutrition. Balkema, Rotterdam, p 449-468

Yamashita M, Iwata F (1983) A quantitative analysis of the annual testicular cycle of the brittle-star Amphipholis kochii by means of autoradiographic investigation. Biol Bull 164:327-340

Zar JH (1999) Biostatistical analysis, 4th edn. Prentice-Hall, Upper Saddle River, NJ

Submitted: May 16, 2013; Accepted: July 27, 2013

Proofs received from author(s): October 31, 2013 